\title{
Trehalose-6-phosphate synthase/phosphatase complex from bakers' yeast: purification of a proteolytically activated form
}

\author{
JOHN LONDESBOROUGH* and OUTI VUORIO \\ Research Laboratories, Alko Ltd, PO Box 350, SF-00101 Helsinki, Finland
}

(Received 27 June 1990; revised 12 September 1990; accepted 15 October 1990)

\begin{abstract}
A protein of about $800 \mathrm{kDa}$ with trehalose-6-phosphate synthase (TPS) and trehalose-6-phosphate phosphatase (TPP) activity was purified from bakers' yeast. This TPS/P complex contained 57, 86 and $93 \mathrm{kDa}$ polypeptides. The 86 and $93 \mathrm{kDa}$ polypeptides both appeared to be derived from a polypeptide of at least $115 \mathrm{kDa}$ in the native enzyme. A TPS-activator (a dimer of $58 \mathrm{kDa}$ subunits) was also purified. It decreased the Michaelis constants for both UDP-glucose (three-fold) and glucose 6-phosphate (G6P) (4-5-fold), and increased TPS activity at 5 mMUDP-glucose/10 mM-G6P about three-fold. It did not affect TPP activity. The purification of TPS/P included an endogenous proteolytic step that increased TPS activity about three-fold and abolished its requirement for TPSactivator, but did not change TPP activity. This activation was accompanied by a decrease of some $20 \mathrm{kDa}$ in the molecular mass of a cluster of SDS-PAGE bands at about $115 \mathrm{kDa}$ recognized by antiserum to pure TPS/P, but by no change in the $57 \mathrm{kDa}$ band. Phosphate inhibited TPS activity ( $K_{\mathrm{i}}$ about $5 \mathrm{mM}$ ), but increased TPP activity about six-fold $\left(K_{\mathrm{a}}\right.$ about $\left.4 \mathrm{mM}\right)$. Phosphate $(6 \mathrm{mM})$ stimulated the synthesis of trehalose from G6P and UDPglucose and decreased the accumulation of trehalose 6-phosphate.
\end{abstract}

\section{Introduction}

Large amounts of trehalose ( $\alpha$-D-glucopyranosyl- $\alpha$-Dglucopyranose) occur in resting cells of bakers' yeast. Lillie \& Pringle (1980) showed that during growth on glucose, accumulation of trehalose began distinctly later than that of glycogen, and that during subsequent starvation, trehalose consumption began only after depletion of the glycogen. Later work has established a strong correlation between the trehalose content of cells of Saccharomyces cerevisiae and their resistance to various stresses, such as temperature extremes and dehydration (Hottiger et al., 1987a, b; Attfield, 1987; Gadd et al., 1987). This correlation holds both for commercial bakers' yeast strains (Oda et al., 1986) and for mutants with defective control of trehalose metabolism (Tenan et al., 1985; Hottiger et al., 1989). It appears that the primary function of trehalose in yeast is not as a C-reserve but as a protectant of cell membranes and proteins under conditions that deplete the activity of intracellular water, a role for which this non-reducing sugar is well suited (Crowe et al., 1987).

Abbreviations: G6P, glucose 6-phosphate; T6P, trehalose 6-phosphate; TPP, trehalose-6-phosphate phosphatase; TPS, trehalose-6-phosphate synthase; TPS/P, trehalose-6-phosphate synthase/phosphatase complex; UDPG, uridine diphosphate glucose.
Trehalose is degraded in yeast by a trehalase that is activated by phosphorylation (reviewed by Thevelein, 1988). Cabib \& Leloir (1958) showed that trehalose is synthesized from uridine diphosphate glucose (UDPG) and glucose 6-phosphate (G6P) via trehalose 6-phosphate (T6P). Since then, rather few publications have dealt with the properties of the enzymes responsible, T6P synthase (TPS) and T6P phosphatase (TPP). In partial purifications, the two enzymes have co-purified (Cabib \& Leloir, 1958; Vandercammen et al., 1989). Inhibition of TPS by physiological concentrations of inorganic phosphate has been noted (Elander, 1968; Vandercammen et al., 1989). Panek's group has claimed that some strains of $S$. cerevisiae contain distinct UDPG- and ADPG-linked TPS enzymes (Paschoalin et al., 1989), and that the UDPG-linked enzyme is reversibly inactivated by phosphorylation (Panek et al., 1987). The latter claim has been contested by Vandercammen et al. (1989), who could find no effect of exposure to phosphorylating conditions either in vivo or in vitro when a reliable TPS assay was used.

This paper reports the purification of a proteolytically modified complex containing both TPS and TPP activities. The purification of a protein that activates the TPS of this complex is also reported. Some catalytic properties of the complex, including its unexpected response to inorganic phosphate, are described. 


\section{Methods}

Materials. Anion exchange resin [AG1-X8 (formate: 200 to 400 mesh)] and hydroxyapatite (Biogel HT) were from BioRad, DEAEcellulose (DE52) from Whatman, UDP-glucuronate-agarose from Sigma, and other chromatographic materials from Pharmacia. $\left[\mathrm{U}^{-1+} \mathrm{C}\right]$ Glucose 6-phosphate was from Amersham. Phenylmethylsulphonyl fluoride (PMSF), pepstatin A, glucose 6-phosphate, nucleotides, marker proteins, lactate dehydrogenase (pig heart), pyruvate kinase (rabbit muscle) and glucose-6-phosphate dehydrogenase (G6PDH) were from Sigma or Boehringer. Anti-rabbit IgG-alkaline phosphatase conjugate was from Promega.

Purification of TPS/P. Bakers' yeast from our Rajamäki factory was disintegrated by suspending $20 \mathrm{~g}$ lots in $20 \mathrm{ml} 25 \mathrm{mM}$-HEPES/KOH (pH 7.0) containing $1 \mathrm{~mm}$-benzamidine, $1 \mathrm{~mm}-\mathrm{MgCl}_{2}, 0.1 \mathrm{mM}$-EDTA and $1 \mathrm{mM}$-dithiothreitol (HBMED), adding $0.4 \mathrm{ml}$ methanol containing $0.1 \mathrm{M}-\mathrm{PMSF}$ and $1 \mathrm{mg}$ pepstatin $\mathrm{A} \mathrm{ml}^{-1}$, and shaking with $50 \mathrm{ml}$ $0.5 \mathrm{~mm}$ diameter glass beads in a Braun MK II homogenizer for two 1 min periods.

The homogenate $\left(0.5 \mathrm{~g}\right.$ yeast $\left.\mathrm{ml}^{-1}\right)$ was centrifuged for $20 \mathrm{~min}$ at $28000 \mathrm{~g}$. More PMSF $(0.5 \mathrm{~mm})$ and pepstatin $\mathrm{A}\left(5 \mu \mathrm{g} \mathrm{ml}^{-1}\right)$ were added to the supernatant. Then $10 \mathrm{ml}$ protamine sulphate $[15 \mathrm{mg}(\mathrm{ml}$ HBMED) $)^{-1}$ ] was added to each $60 \mathrm{ml}$ of supernatant. After $20 \mathrm{~min}$ the precipitate was discarded $(20 \mathrm{~min}$ at $12000 \mathrm{~g})$.

To every $50 \mathrm{ml}$ of supernatant was slowly added $16.5 \mathrm{~g}$ powdered $\left(\mathrm{NH}_{4}\right)_{2} \mathrm{SO}_{4}$. After $40 \mathrm{~min}$, precipitated proteins were collected (10 min at $28000 \mathrm{~g}$ ) and dissolved in HBMED. PMSF $(0.7 \mathrm{mM})$ and pepstatin A $\left(7 \mu \mathrm{g} \mathrm{ml}^{-1}\right)$ were added, insoluble material was removed $(5 \mathrm{~min}$ at $28000 \mathrm{~g}$ ) and the solution was stored at $-70^{\circ} \mathrm{C}$.

Material from $50 \mathrm{~g}$ yeast was thawed. PMSF $(0.3 \mathrm{~mm})$ and pepstatin A $\left(3 \mu \mathrm{g} \mathrm{ml}^{-1}\right)$ were added and the solution centrifuged for $10 \mathrm{~min}$ at $8000 \mathrm{~g}$. The supernatant $(22 \mathrm{ml})$ was passed in two equal portions through a column $(2.5 \times 17 \mathrm{~cm})$ of Sephadex G25 equilibrated with HBMED $/ 0.1 \mathrm{M}-\mathrm{KCl}$ and then applied at $13 \mathrm{ml} \mathrm{h}^{-1}$ to a column $(2.5 \times 13 \mathrm{~cm})$ of Heparin-Sepharose equilibrated with HBMED $/ 0.1 \mathrm{M}^{-}$ $\mathrm{KCl}$. The column was washed with $200 \mathrm{ml} \mathrm{HBMED} / 0 \cdot 1 \mathrm{M}-\mathrm{KCl}$ and developed with a linear gradient of $0 \cdot 1-1.5 \mathrm{M}-\mathrm{KCl}$ in $500 \mathrm{ml}$ HBMED at $24 \mathrm{ml} \mathrm{h}^{-1}$ (see Fig. 2).

TPS active fractions were kept at about $3{ }^{\circ} \mathrm{C}$ for $5 \mathrm{~d}$ without PMSF or pepstatin $\mathrm{A}$. Their activity increased two- to three-fold. To the pooled

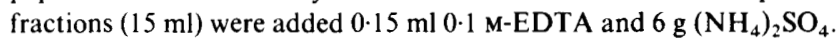
After $40 \mathrm{~min}$ the precipitate was collected $(15 \mathrm{~min}$ at $8000 \mathrm{~g})$, dried (5 $\mathrm{min}$ at $17000 \mathrm{~g}$ ) and dissolved in $2 \mathrm{ml}$ HBMED. PMSF (0.5 mM) and pepstatin $A\left(5 \mu \mathrm{g} \mathrm{ml}^{-1}\right)$ were added and insoluble material was removed $(10 \mathrm{~min}$ at $17000 \mathrm{~g})$.

The supernatant was passed at $20 \mathrm{ml} \mathrm{h}^{-1}$ through a column $(2.8 \times 32 \mathrm{~cm})$ of Sepharose 6B equilibrated with HBMED. Fractions from the leading half of the enzyme peak were pooled and run at $9 \mathrm{ml}$ $\mathrm{h}^{-1}$ into a column $(0.7 \times 7.3 \mathrm{~cm})$ of UDP-glucuronate-agarose equilibrated with HBMED. The column was washed with $10 \mathrm{ml}$ HBMED. Bound proteins were eluted at $4.5 \mathrm{ml} \mathrm{h}^{-1}$ with about $20 \mathrm{ml}$ HBMED $/ 0 \cdot 2 \mathrm{M}-\mathrm{NaCl}$ (until the $\boldsymbol{A}_{280}$ of the eluate indicated no more protein was being eluted) and then with $\mathrm{HBMED} / 0 \cdot 4 \mathrm{M}-\mathrm{NaCl} / 10 \mathrm{mM}-$ UDPG.

Purification of TPS activator. The Heparin-Sepharose fractions containing TPS-activator were pooled (see Fig. 2) and centrifuged for $10 \mathrm{~min}$ at $12000 \mathrm{~g}$. To $20 \mathrm{ml}$ of the supernatant was added $0.2 \mathrm{ml} 0.1 \mathrm{M}-$ EDTA and $7.0 \mathrm{~g}\left(\mathrm{NH}_{4}\right)_{2} \mathrm{SO}_{4}$. The precipitate was discarded. A further $2 \cdot 3 \mathrm{~g}\left(\mathrm{NH}_{4}\right)_{2} \mathrm{SO}_{\downarrow}$ was added. The precipitate was collected $(10 \mathrm{~min}$ at $28000 \mathrm{~g}$ ) amd dissolved in $2.0 \mathrm{ml}$ HBMED. PMSF (I mM) and pepstatin $\mathrm{A}\left(10 \mu \mathrm{g} \mathrm{ml}^{-1}\right)$ were added.

The solution was run at $37 \mathrm{ml} \mathrm{h}^{-1}$ through a column $(2.6 \times 34 \mathrm{~cm})$ of Sephadex G 100 equilibrated with $25 \mathrm{~mm}-\mathrm{HEPES} / \mathrm{KOH}(\mathrm{pH}$
$7 \cdot 0) / 1 \mathrm{mM}-\mathrm{MgCl}_{2} / 0 \cdot 1 \mathrm{mM}$-EDTA (HME). TPS-activator emerged between the elution volumes of $\gamma$-globulin $(55 \mathrm{ml})$ and bovine albumin (72 ml).

The most active fractions ( 57 to $72 \mathrm{ml}$ ) were applied to a column $(0.7 \times 4.7 \mathrm{~cm})$ of DE52-cellulose equilibrated with HME. The column was developed with a linear gradient of 0.0 to $0.5 \mathrm{M}-\mathrm{NaCl}$ in $100 \mathrm{ml}$ HME at $7 \mathrm{ml} \mathrm{h}^{-1}$ and $2.2 \mathrm{ml}$ fractions were collected. The activator eluted sharply at about $50 \mathrm{~mm}-\mathrm{NaCl}$.

The purest fraction $(2.2 \mathrm{ml})$ was applied to a column $(0.7 \times 4.5 \mathrm{~cm})$ hydroxyapatite equilibrated with HME. The column was developed at $2 \mathrm{ml} \mathrm{h}^{-1}$ with a linear gradient of 0 to $10 \%(\mathrm{w} / \mathrm{v})\left(\mathrm{NH}_{4}\right)_{2} \mathrm{SO}_{4}$ in $60 \mathrm{ml}$ HME. The activator emerged between 3 and $4 \%(\mathrm{w} / \mathrm{v})\left(\mathrm{NH}_{4}\right)_{2} \mathrm{SO}_{4}$.

Enzyme assays. Enzymes were assayed at $30^{\circ} \mathrm{C}$. The amount of enzyme producing $1 \mu \mathrm{mol}$ product $\mathrm{min}^{-1}$ in the respective standard assay is $1 \mathrm{U}$. Samples were diluted, when necessary, with $50 \mathrm{~mm}$ HEPES/KOH (pH7.0)/0.1 mM-EDTA/ $5 \mathrm{mg}$ bovine albumin $\mathrm{ml}^{-1}$, because the TPS activity was unstable at low protein concentrations.

TPS was assayed by a modification of the method of Cabib \& Leloir (1958). Standard assay mixtures ( $100 \mu \mathrm{l}$ final volume) contained $40 \mathrm{~mm}$ HEPES/KOH (pH 6.8), $10 \mathrm{~mm}-\mathrm{MgCl}_{2}, 10 \mathrm{~mm}-\mathrm{G} 6 \mathrm{P}, 5 \mathrm{~mm}-\mathrm{UDPG}$ and $1 \mathrm{mg}$ bovine albumin $\mathrm{ml}^{-1}$. Reactions were started with enzyme and stopped after appropriate times (a zero and two times between 1 and 10 $\mathrm{min}$ ) by placing the tubes in boiling water for $2 \mathrm{~min}$. UDP in the cooled reaction mixtures was determined by adding $0.9 \mathrm{ml} 40 \mathrm{mM}$-HEPES/ $\mathrm{KOH}$ ( $\mathrm{pH} \mathrm{6.8)}$ containing $10 \mathrm{mM}-\mathrm{MgCl}_{2}, 2.5 \mathrm{~mm}$-phosphoenolpyruvate and $0.24 \mathrm{~mm}-\mathrm{NADH}$, centrifuging to remove precipitated protein, and measuring spectrophotometrically at $340 \mathrm{~nm}$ the disappearance of NADH on addition of pyruvate kinase and lactate dehydrogenase. When substrate concentrations were varied in TPS assays, rates at each concentration were measured over two different time intervals. They generally agreed within $10 \%$, and the mean was used. However, when a significant amount of substrate was consumed $(\geq 15 \%$ at initial concentrations below $K_{\mathrm{m}}$ ), the rate from each time interval was handled separately and plotted against the average substrate concentration in the time interval, as recommended by Glick et al. (1979).

TPP was assayed by measuring the production of $\left[{ }^{14} \mathrm{C}\right]$ trehalose from $\left[{ }^{14} \mathrm{C}\right]$ trehalose 6-phosphate $\left(\left[{ }^{14} \mathrm{C}\right]-\mathrm{T} 6 \mathrm{P}\right)$. Standard assay mixtures (110 $\mu$ l final volume) contained $25 \mathrm{~mm}$-potassium phosphate ( $\mathrm{pH} \mathrm{6.8)}$ ), $5 \mathrm{mM}-\mathrm{MgCl}_{2}, 0.5 \mathrm{~mm}-\left[{ }^{14} \mathrm{C}\right] \mathrm{T} 6 \mathrm{P}\left(924\right.$ c.p.m. nmol $\left.{ }^{-1}\right)$ and $1 \mathrm{mg}$ bovine albumin $\mathrm{ml}^{-1}$. Reactions were started with enzyme and stopped after appropriate intervals (a zero and two times between $1 \mathrm{~min}$ and $20 \mathrm{~min}$ ) by immersion in boiling water. $\mathrm{AGl}-\mathrm{X} 8$ (formate) anion-exchange resin $\left(1.0 \mathrm{ml}\right.$ of a slurry made by mixing $300 \mathrm{~g}$ resin with $730 \mathrm{ml} \mathrm{H}_{2} \mathrm{O}$ to give 1 litre; $1.0 \mathrm{ml}$ of slurry contained $0.86 \mathrm{ml}$ of liquid because the moisture content of the slurry was $44 \%$ ) was added to each tube. After 20 min equilibration, the tubes were centrifuged. The radioactivity of supernantant samples $(400 \mu \mathrm{l})$ was measured by liquid scintillation counting. With fresh reaction mixtures less than $2 \%$ of the total radioactivity remained in the supernatant when enzyme was omitted (much higher blanks were obtained with the chloride form of the resin). When reactions were allowed to go to completion, $100 \pm 5 \%$ of the total radioactivity was recovered in the supernantant.

The overall reaction from UDPG and G6P to trehalose was measured as follows. Reaction mixtures $(1 \mathrm{ml})$ contained $50 \mathrm{~mm}$ HEPES/KOH (pH 6.8), $5 \mathrm{~mm}-\mathrm{MgCl}_{2}, 5 \mathrm{~mm}-\mathrm{UDPG}, 4.25 \mathrm{~mm}-$ $\left[{ }^{14} \mathrm{C}\right] \mathrm{G} 6 \mathrm{P}\left(870\right.$ c.p.m. nmol $\left.{ }^{-1}\right), 1 \mathrm{mg}$ bovine albumin $\mathrm{ml}^{-1}$ and zero or $6 \mathrm{~mm}$-potassium phosphate $(\mathrm{pH} 6 \cdot 8)$. UDP and $\left[{ }^{4} \mathrm{C}\right]$ trehalose were determined in duplicate $100 \mu \mathrm{l}$ samples as described for the TPS and TPP assays. T6P was calculated as the difference between the UDP and trehalose. Because the T6P formed binds less tightly to the AG1-X8 resin than does $\mathrm{G} 6 \mathrm{P}$, the blank increases during the reaction. Apparent trehalose concentrations were corrected accordingly (this negative correction decreased with time from $\leqslant 14 \%$ at $5 \mathrm{~min}$ to $\leqslant 6 \%$ at 20 $\min )$. 
Table 1. Purification of TPS/P complex

The data are from the particular preparation described in Methods. Several other preparations have been performed with similar results. Protein was determined according to Warburg \& Christian (1941)(W) or by assuming an $A_{288}^{1 \%}$ of 10 . Values in parentheses for the TPS/TPP ratio were determined in another preparation. ND, Not determined.

\begin{tabular}{|c|c|c|c|c|c|c|}
\hline \multirow{2}{*}{$\begin{array}{l}\text { Purification } \\
\text { Step }\end{array}$} & \multirow{2}{*}{$\begin{array}{l}\text { Volume } \\
\text { (ml) }\end{array}$} & \multirow{2}{*}{$\begin{array}{l}\text { Protein } \\
\left(\mathrm{mg} \mathrm{ml}^{-1}\right)\end{array}$} & \multicolumn{2}{|c|}{ TPS } & \multirow{2}{*}{$\begin{array}{l}\text { TPP } \\
(\mathrm{U})\end{array}$} & \multirow{2}{*}{$\begin{array}{c}\text { TPP/TPS } \\
(\%)\end{array}$} \\
\hline & & & $\left(\mathrm{U} \mathrm{mg} \mathrm{m}^{-1}\right)$ & (U) & & \\
\hline Homogenate & 106 & ND & ND & 780 & ND & (34) \\
\hline After protamine sulphate & 79 & $20(W)$ & $0 \cdot 38$ & 590 & ND & (36) \\
\hline 1st $\left(\mathrm{NH}_{4}\right)_{2} \mathrm{SO}_{4}$ precipitate & 19 & $52(W)$ & $0 \cdot 60$ & 570 & ND & ND \\
\hline Sephadex G25 eluate & 42 & 30 & 0.31 & 394 & 122 & 31 \\
\hline \multicolumn{7}{|l|}{ Heparin-Sepharose eluate: } \\
\hline Fresh & 17 & 4 & $0 \cdot 80$ & 54 & 22 & 41 \\
\hline $5 \mathrm{~d}$ old & 17 & 4 & $2 \cdot 4$ & 159 & 22 & 14 \\
\hline 2nd $\left(\mathrm{NH}_{4}\right)_{2} \mathrm{SO}_{4}$ precipitate & $1 \cdot 4$ & $41(W)$ & 1.9 & 106 & ND & ND \\
\hline Sepharose 6B eluate & 20 & $0 \cdot 11$ & 15 & $33^{*}$ & ND & ND \\
\hline \multicolumn{7}{|c|}{ UDP-glucuronate-agarose eluate: } \\
\hline $0.2 \mathrm{M}-\mathrm{NaCl}$ & $7 \cdot 5$ & 0.09 & $1 \cdot 1$ & $0 \cdot 8$ & ND & ND \\
\hline $0.4 \mathrm{M}-\mathrm{NaCl} / 10 \mathrm{~mm}-\mathrm{UDPG}$ & $7 \cdot 2$ & ND & ND $\dagger$ & 13 & $2 \cdot 6$ & 20 \\
\hline
\end{tabular}

* A further $36 \mathrm{U}$ (at $3.8 \mathrm{U} \mathrm{mg}^{-1}$ ) was discarded.

† Coomassie blue staining indicated about $25 \mathrm{U} \mathrm{mg}^{-1}$.

\begin{abstract}
Preparation of $\left[{ }^{14} \mathrm{C}\right] T 6 \mathrm{P} .\left[{ }^{14} \mathrm{C}\right] \mathrm{T} 6 \mathrm{P}$ was made by a modification of the method of Vandercammen et al. (1989) by using TPS/P in the presence of excess EDTA, which inhibits the TPP activity but not the TPS. $\left[\mathrm{U}-{ }^{14} \mathrm{C}\right] \mathrm{G} 6 \mathrm{P}$ (assayed with G6PDH:87.0 $\mu \mathrm{mol} ; 924$ c.p.m. $\left.\mathrm{nmol}{ }^{-1}\right)$ and UDPG $(100 \mu \mathrm{mol})$ were incubated for $4 \mathrm{~h}$ at $30^{\circ} \mathrm{C}$ with $0.7 \mathrm{U}$ pure TPS/P in $40 \mathrm{mM}$-HEPES/KOH ( $\mathrm{pH} \mathrm{7.0)/0.9} \mathrm{mM-EDTA/0.9}$ $\mathrm{mg}$ bovine albumin $\mathrm{ml}^{-1}$. The reaction mixture was then heated at $100{ }^{\circ} \mathrm{C}$ for $5 \mathrm{~min}$, cooled, mixed with 2 vols ethanol, and centrifuged. The supernatant was dried at $60^{\circ} \mathrm{C}$ under a stream of $\mathrm{N}_{2}$. The residue was dissolved in $4 \mathrm{ml} 0.1 \mathrm{M}-\mathrm{NaOH}$, heated at $80^{\circ} \mathrm{C}$ for $15 \mathrm{~min}$, adjusted to $\mathrm{pH} 5.7$ with $1 \mathrm{M}-\mathrm{H}_{3} \mathrm{PO}_{4}$ and applied to a column $(2.5 \times 17 \mathrm{~cm})$ of AGl-X8 (formate form) anion exchanger in $\mathrm{H}_{2} \mathrm{O}$. The column was developed at $50 \mathrm{ml} \mathrm{h}{ }^{-1}$ with $0.1 \mathrm{M}-\mathrm{NH}_{4} \mathrm{H}_{2} \mathrm{PO}_{4}(\mathrm{pH} 4 \cdot 5)$. $\left[{ }^{1+} \mathrm{C}\right] \mathrm{T} 6 \mathrm{P}$ $(43 \mu \mathrm{mol})$ was eluted between 460 and $560 \mathrm{ml}$, before the G6P peak at $600 \mathrm{ml}$. The $\left[{ }^{14} \mathrm{C}\right] \mathrm{T} 6 \mathrm{P}$ fractions were lyophilized. The residues were maintained under vacuum for $24 \mathrm{~h}$ to remove ammonium formate (which inhibits TPP), dissolved in $\mathrm{H}_{2} \mathrm{O}$ to about $20 \mathrm{mM}$ and stored at $-18^{\circ} \mathrm{C}$.
\end{abstract}

Electrophoresis. SDS-PAGE was performed essentially as described by Laemmli (1970). For Western blotting, samples run on $70 \times 100 \times 0.75 \mathrm{~mm}$ gels were blotted onto nitrocellulose, probed with antiserum as described in Fig. 5 and detected with goat anti-rabbit IgG-alkaline phosphatase conjugate (1/7500) from Promega according to the manufacturer's instructions.

Preparation of antisera. Antisera were prepared for us at the National Public Health Institute (Helsinki). Rabbits were injected with $0.2 \mathrm{ml}$ of a 1:1 mixture of Freund's complete adjuvant and antigen (about $20 \mu \mathrm{g}$ protein) into both popliteal lymph nodes. Booster injections were given after 2 and 6 weeks, and the animals bled out 1 week after the last injection. The antigens used were pure TPS/P (the preparation shown in Fig. 1), and 93 and $57 \mathrm{kDa}$ polypeptides isolated by SDS-PAGE, located by immersing the gel in cold $0.5 \mathrm{M}-\mathrm{KCl}$ (Hager \& Burgess, 1980), cut out and eluted

Peptide mapping. The 57,86 , and $93 \mathrm{kDa}$ polypeptides were separated by SDS-PAGE in an $8 \%(\mathrm{w} / \mathrm{v}) \mathrm{T}$ acrylamide gel (aged for $48 \mathrm{~h}$ ), blotted overnight and digested on the nitrocellulose with trypsin essentially as described by Aebersold et al. (1987). The peptides were separated by reverse-phase chromatography at $1 \mathrm{ml} \mathrm{min}^{-1}$ on a Vydac 218 TP B5 column $(0.46 \times 25 \mathrm{~cm}$; The Sep/a/ra/tions Group $)$ with a gradient from $0.1 \%$ trifluoroacetic acid to $60 \%(\mathrm{v} / \mathrm{v})$ acetonitrile $/ 0.04 \%$ trifluoroacetic acid in $90 \mathrm{~min}$. The eluate was monitored at $218 \mathrm{~nm}$.

\section{Results}

\section{Purification of TPS/S complex}

A typical purification is summarized in Table 1. SDSPAGE analysis of purified TPS/P is shown in Fig. 1. The ratio of TPP and TPS activities was between 14 and $41 \%$ throughout the purification, suggesting the final product is a complex with both activities. The overall yield of TPS was low $(1.7 \%$ in Table $1 ; 4 \%$ in our best preparation). Much TPS activity was lost during chromatography on Heparin-Sepharose because of resolution of an activator of TPS from TPS/P (see below and Fig. 2). However, the TPS activity of Heparin-Sepharose eluates increased by 2.5 to 4 -fold during storage (see below). TPS/P was eluted from Sepharose $6 \mathrm{~B}$ before the elution volume of ferritin, with an apparent molecular mass of about $800 \mathrm{kDa}$ (not shown), and the more contaminated tailing half of the enzyme peak was discarded. Often (but not in the example shown in Table 1) 20 to $50 \%$ of the enzyme eluted from the UDPglucuronate-agarose column in the $0.2 \mathrm{M}-\mathrm{NaCl}$ wash.

The three major polypeptides in the purified enzyme had molecular masses of $57 \mathrm{kDa}$, about $86 \mathrm{kDa}$ and $93 \mathrm{kDa}$ (Fig. 1). The $86 \mathrm{kDa}$ band was often a doublet. 
(a)

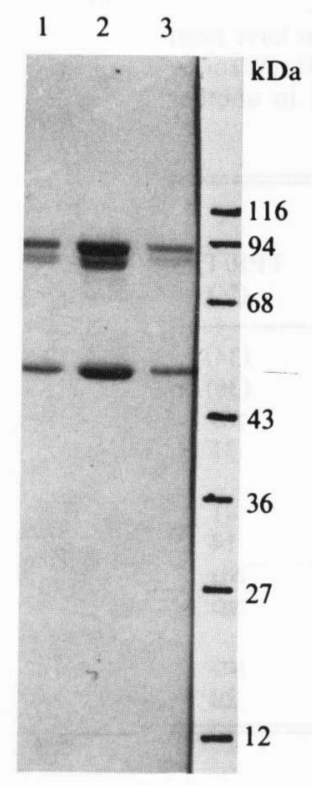

(b)

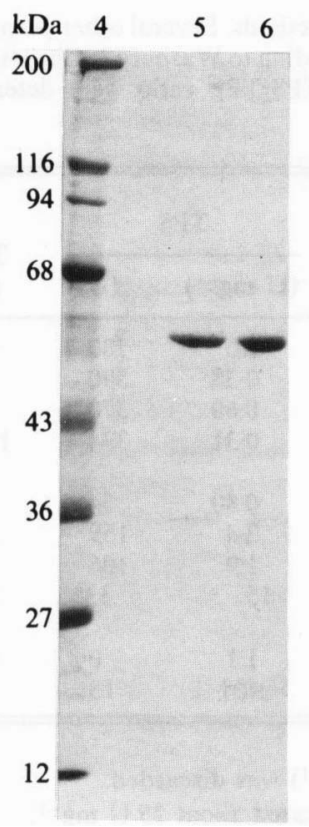

Fig. 1. SDS-PAGE of purified TPS/P and TPS-activator. Gels were stained with Coomassie blue. (a) Lanes 1, 2 and 3 contained 25, 106 and $24 \mathrm{mU}$ of TPS, respectively, from successive fractions eluted from UDP-glucuronate-agarose with $0 \cdot 4 \mathrm{M}-\mathrm{NaCl} / 10 \mathrm{~mm}$-UDPG. The positions of molecular mass standards are shown on the right. (b) Lane 4, standard proteins; lanes 5 and $6,1.3$ and $1.9 \mu \mathrm{g}$ (assuming an $A_{280}^{1 \%}$ of 10) of TPS-activator from successive fractions eluted from hydroxyapatite.

Peptide maps of tryptic digests of blots of the 86 and $93 \mathrm{kDa}$ polypeptides were essentially identical (not shown). This suggests that the $86 \mathrm{kDa}$ polypeptide is a degradation product of the $93 \mathrm{kDa}$ polypeptide. In contrast, the peptide map of the $57 \mathrm{kDa}$ polypeptide was clearly distinct (not shown), and the $57 \mathrm{kDa}$ polypeptide did not cross-react with antiserum against the $93 \mathrm{kDa}$ polypeptide (see Fig. 5). When the bands were cut out of stained (but undried) gels and Coomassie blue eluted with $4 \%(\mathrm{w} / \mathrm{v})$ SDS and determined at $560 \mathrm{~nm}$, relative colour yields of $1.00(57 \mathrm{kDa}), 0.34 \pm 0.20(86 \mathrm{kDa})$ and $0.79 \pm 0.07(93 \mathrm{kDa})$ were found in four analyses of three different samples. Gels stained with Fast Green gave similar results. If the bands have equivalent affinities for the dyes, then these data suggest a molar ratio of about 1.4 for the $57 \mathrm{kDa}$ polypeptide to the sum of the 93 and $86 \mathrm{kDa}$ polypeptides.

\section{TPS activator}

Fig. 2 shows the chromatographic resolution of an activator of TPS, from the TPS/P enzyme. The inset shows that TPP activity was unaffected by amounts of this TPS-activator that had a nearly saturating effect on the TPS activity. The maximum activation in Fig. 2 was 2.5-fold. Activations of up to four-fold have been obtained with some TPS/P samples. The inset of Fig. 2 shows that $3 \mu$ of the fraction with most TPS-activator caused a $90 \%$ of maximal activation of $7.1 \mathrm{mU}$ of TPS.

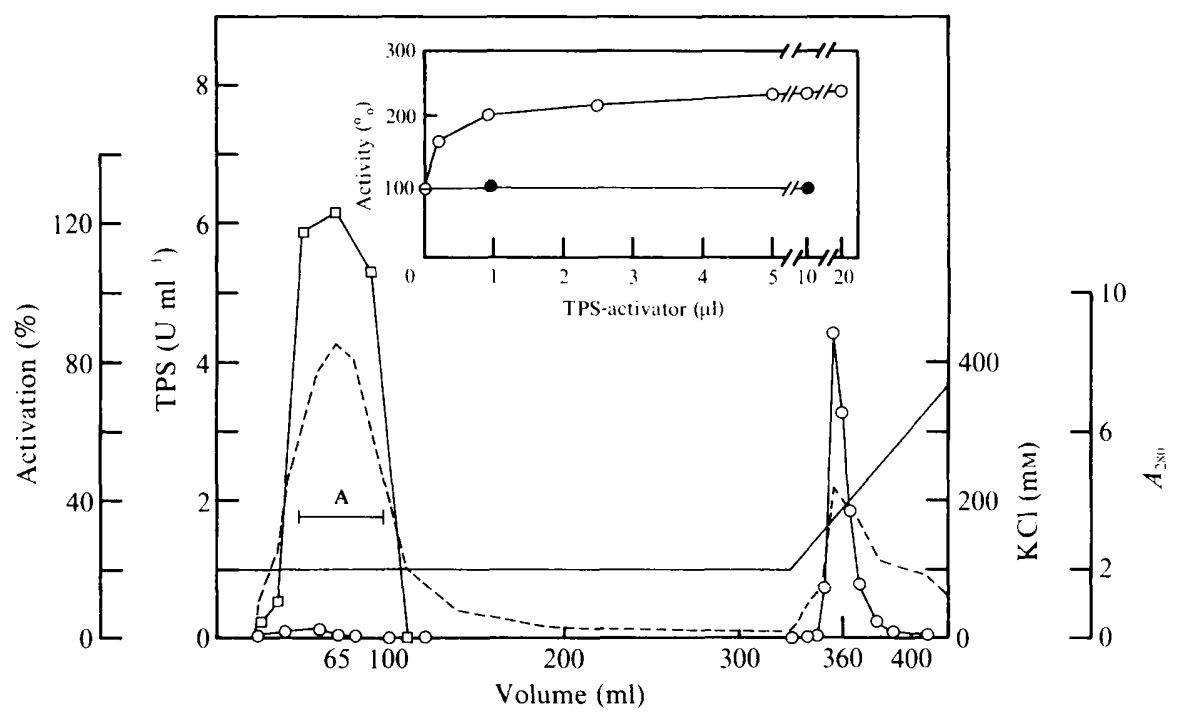

Fig. 2. Separation of TPS-activator from the enzyme. Partially purified TPS/P (394 U of TPS) was chromatographed on HeparinSepharose as described in Methods. The $A_{280}(--), \mathrm{KCl}$ gradient (-), TPS activity (O) and TPS-activator ( $\square$ ) are shown. The bar marked A shows the fractions pooled for purification of TPS-activator. TPS-activator was assayed by measuring the TPS activity of $1.7 \mu \mathrm{l}(7.1 \mathrm{mU})$ of the fraction at $360 \mathrm{ml}$ in the presence and absence of $5 \mu \mathrm{l}$ of fractions collected between 20 and $120 \mathrm{ml}$. The inset shows the effect of various amounts of the TPS-activator-containing fraction eluted at $65 \mathrm{ml}$ on the TPS $(0)$ and TPP $(\bullet)$ activities of $1.7 \mu$ of the fraction eluted at $360 \mathrm{ml}$. Variations in the size of the response of TPS to TPS-activator (from 2-to 4-fold) are described in the text. 


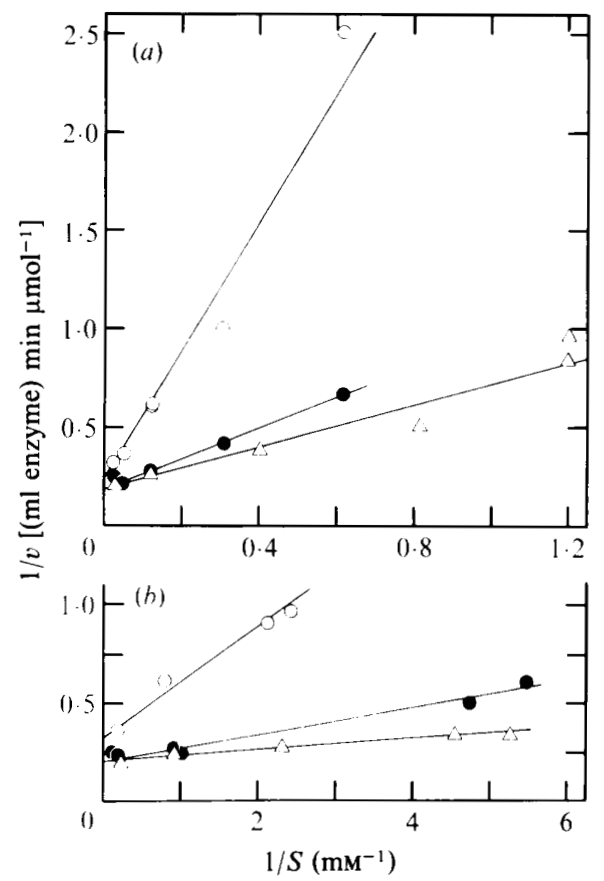

Fig. 3. Effect of TPS-activator on the Michaelis constants of 'native' TPS/P. TPS/P eluted from Heparin-Sepharose and stored at $-70^{\circ} \mathrm{C}$ in the presence of PMSF was used at $53 \mathrm{mU}$ (ml reaction mixture $)^{-1}$ in the presence $(\bullet)$ and absence $(O)$ of $2.5 \mu \mathrm{g} \mathrm{ml}^{-1}$ of pure TPS-activator. Rates $\left[v: \mu \mathrm{mol} \mathrm{min}^{-1}(\mathrm{ml} \text { enzyme })^{-1}\right]$ were measured in standard assay mixtures but with variable substrate concentrations $(S)$ of $(a) 1.6$ to $41 \mathrm{~mm}-\mathrm{G} 6 \mathrm{P}$ at $5 \mathrm{~mm}-\mathrm{UDPG}$ and $(b) 0.18$ to $12.5 \mathrm{~mm}-\mathrm{UDPG}$ at $25 \mathrm{~mm}-$ G6P. Also shown (with $r$ in arbitrary units) are results $(\triangle)$ with pure TPS/P in the absence of TPS-activator. Assays were run for at least two time intervals at each initial substrate concentration and handled as described in Methods.

Based on this result, the total amount of TPS-activator recovered from the Heparin-Sepharose column was nearly enough to maximally activate all the TPS (68 U) recovered from the column. In agreement with this, TPS activity in crude yeast extracts and the material applied to Heparin-Sepharose was increased by less than $7 \%$ by addition of partially purified TPS-activator.

TPS-activator was completely destroyed by $10 \mathrm{~min}$ incubation at $70{ }^{\circ} \mathrm{C}$, but maintained about $50 \%$ activity through $10 \mathrm{~min}$ at $55^{\circ} \mathrm{C}$. Gel-filtration indicated a native molecular mass of about $110 \mathrm{kDa}$ (see Methods). SDSPAGE analysis of pure TPS-activator showed a single Coomassie blue band, with a molecular mass of $58 \mathrm{kDa}$ (Fig. 1). These results suggest that TPS-activator is a dimeric protein. TPS-activator migrated more slowly than the $57 \mathrm{kDa}$ polypeptide of TPS/P during coelectrophoresis on SDS-PAGE, and was not recognized by antiserum prepared against pure TPS/P (not shown).

Pure TPS-activator activated enzyme eluted from Heparin-Sepharose with a saturation curve similar in form to that in the inset of Fig. 2, and $500 \mathrm{ng}$ of activator

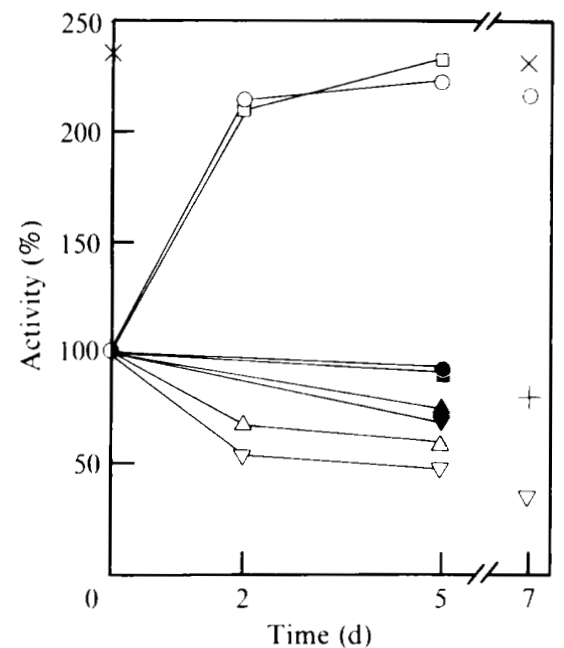

Fig. 4. Spontaneous activation of Heparin-Sepharose eluates. The TPS (open symbols) and TPP (filled symbols) activities were measured in the absence of TPS-activator during storage at $3{ }^{\circ} \mathrm{C}$ of enzyme eluted from Heparin-Sepharose. The samples contained no protease inhibitor $(O, \bullet)$, pepstatin $A(\square, \square)$, PMSF $(\triangle, \Delta)$ or both pepstatin $A$ and $\operatorname{PMSF}(\nabla, \nabla)$. Also shown are the TPS activities measured in the presence of a saturating amount of TPS-activator for a sample stored for 0 and $7 \mathrm{~d}$ without protease inhibitors $(x)$ and for a sample stored for $7 \mathrm{~d}$ with both pepstatin $\mathrm{A}$ and PMSF $(+)$. Two independent experiments are shown. In one, the original TPS and TPP activities were 1.86 and $0.77 \mathrm{U} \mathrm{ml}^{-1}$, respectively, and assays were made at 0,2 and $5 \mathrm{~d}$. In the other, the original TPS was $2.57 \mathrm{U} \mathrm{ml}^{-1}$ and assays were made at 0 and $7 \mathrm{~d}$.

was enough to completely activate ( $2 \cdot 45$-fold) $18 \mathrm{mU}$ of the enzyme (not shown). This amount of 'native' enzyme is equivalent to about $50 \mathrm{mU}$ or $2000 \mathrm{ng}$ of purified TPS/P. These results are consistent with the notion that TPS-activator binds stoichiometrically to TPS/P, but are not accurate enough to define the molar ratio.

TPS-activator decreased the apparent Michaelis constants of 'native' enzyme (from 15 to $3.3 \mathrm{~mm}$ for G6P and from 1.0 to $0.34 \mathrm{~mm}$ for UDPG) towards the values ( $2.5 \mathrm{mM} \mathrm{G6P}$ and $0.16 \mathrm{mM}$ UDPG) observed for pure $\mathrm{TPS} / \mathrm{S}$ in the absence of TPS-activator (Fig. 3).

\section{Proteolytic activation of TPS after Heparin-Sepharose chromatography}

When enzyme eluted from Heparin-Sepharose was stored at 0 to $7{ }^{\circ} \mathrm{C}$ for a few days, the TPS activity increased 2.5 to 4 -fold (there was some variation between fractions and different preparations) but the TPP activity remained nearly constant (Table 1, Fig. 4). This spontaneous activation was not prevented by pepstatin A $\left(10 \mu \mathrm{g} \mathrm{ml}^{-1}\right)$ but was prevented by the serine protease inhibitor PMSF (1 mM): with PMSF the activity decreased by about $40 \%$ (Fig. 4). The spontaneous 


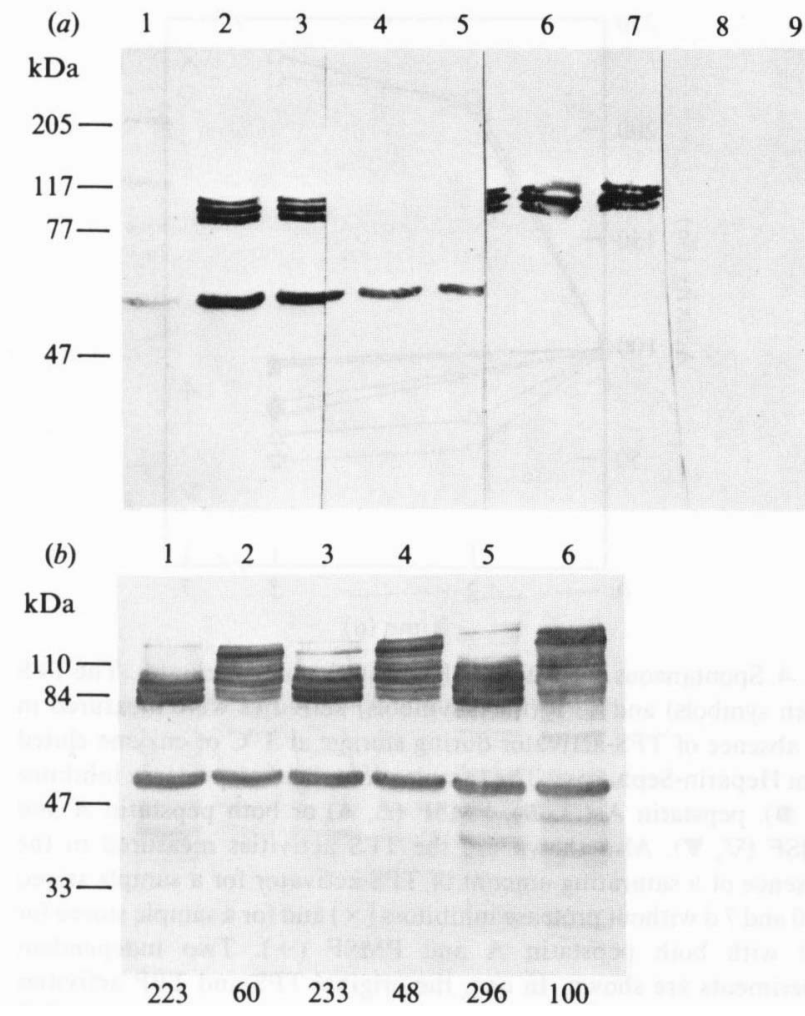

Fig. 5. Molecular mass changes during proteolytic activation. In (a) pure TPS/P (4.4 mU per lane) was electrophoresed and blotted as described in Methods. The blot was cut into four pieces, which were probed with (lanes 1 to 3$)$ antiserum against pure TPS/P ( $1: 30000$ dilution), (lanes 4 and 5) antiserum against isolated $57 \mathrm{kDa}$ polypeptide $(1: 40000$ ), (lanes 6 and 7) antiserum against isolated $93 \mathrm{kDa}$ polypeptide $(1: 20000)$, or (lanes 8 and 9) pre-immune serum $(1: 30000)$. In $(b)$ enzyme freshly eluted from Heparin-Sepharose or enzyme stored for $5 \mathrm{~d}$ was boiled in $2 \%$ SDS, electrophoresed and blotted. The blot was probed with antiserum $(1: 10000)$ to pure TPS/P. Lanes 1 to 4 contained $4.3 \mathrm{mU}\left(0.54 \mathrm{U} \mathrm{mg}^{-1}\right)$ original activity of enzyme stored with (lane 1) no addition, (lane 2) PMSF, (lane 3) pepstatin A and (lane 4) PMSF and pepstatin A. Lanes 5 and 6 contained $10 \mathrm{mU}\left(1.0 \mathrm{U} \mathrm{mg}^{-1}\right)$ original activity of (lane 5) enzyme stored with no addition and (lane 6) freshly eluted enzyme. Numbers below the lanes show the activity at the time of boiling in $2 \%$ SDS, as percentages of the original activity. Molecular mass scales are on the left.

activation increased the TPS activity measured in the absence of TPS-activator to about that of freshly eluted enzyme measured with saturating amounts of TPSactivator. Furthermore, after spontaneous activation the enzyme became insensitive to TPS-activator (only $7 \%$ activation after $7 \mathrm{~d}$ storage) whereas enzyme stored in the presence of PMSF and pepstatin A could still be activated $2 \cdot 3-$ fold even though it had lost $65 \%$ of its fresh activity (Fig. 4).

Western blots (Fig. 5) showed that during storage of the Heparin-Sepharose eluates there was a decrease in the molecular mass of the polypeptides recognized by

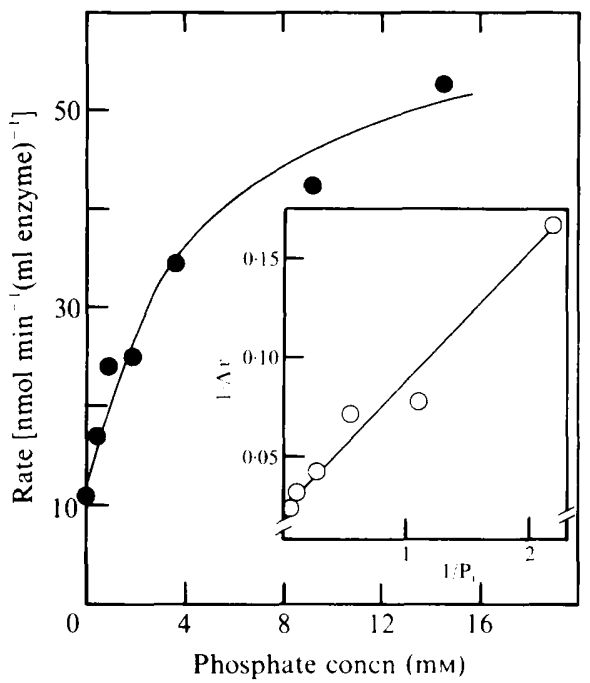

Fig. 6. Activation of TPP by potassium phosphate. TPP activity was measured in reaction mixtures containing $50 \mathrm{mM}-\mathrm{HEPES} / \mathrm{KOH}(\mathrm{pH}$ 6.8), $5 \mathrm{mM}-\mathrm{MgCl}_{2}, 0.24 \mathrm{mM}-\left[{ }^{14} \mathrm{C}\right] \mathrm{T} 6 \mathrm{P}, 1 \mathrm{mg}$ ovalbumin $\mathrm{ml}^{-1}$ and the indicated concentrations of potassium phosphate ( $\mathrm{pH} \mathrm{6.8)}$. The points are means of duplicates that were within $\pm 12 \%$ of the mean, except at $0.45 \mathrm{~mm}$-phosphate $( \pm 26 \%)$. The inset shows the reciprocal of the increase in reaction rate above that without phosphate $[1 / \Delta v,(\mathrm{ml}$ enzyme) $\min \mathrm{nmol}^{-1}$ ] as a function of the reciprocal of the phosphate concentration $\left(1 / \mathrm{P}_{\mathrm{i}}, \mathrm{mM}^{-1}\right)$.

antiserum prepared against purified TPS/P complex. The antiserum recognised a band in the HeparinSepharose eluates at about $57 \mathrm{kDa}$ which did not change during storage and presumably corresponds to the $57 \mathrm{kDa}$ Coomassie-blue-stained band in pure TPS/P. It also recognized a cluster of bands between about 90 and $115 \mathrm{kDa}$. Within this cluster, the strongest bands in fresh preparations of enzyme or enzyme stored in the presence of PMSF were above $110 \mathrm{kDa}$, whereas after $5 \mathrm{~d}$ storage without PMSF these bands had almost disappeared and bands at about 90 to $100 \mathrm{kDa}$ became much stronger.

These results suggest that the 'native' TPS/P in fresh Heparin-Sepharose eluates became proteolytically modified in such a way that full TPS activity no longer required TPS-activator. Varying extents of proteolytic modification, either in vivo or during early purification steps, might explain why the sensitivity to TPS-activator and the amount of activation during storage varied from preparation to preparation.

\section{Catalytic activity}

As previously reported for crude enzyme preparations (Cabib \& Leloir, 1958; Elander, 1968), free divalent metal ions were not essential for the TPS activity of pure TPS/P but $\mathrm{Mg}^{2+}$ ions promoted the reaction. TPS rates at $1 \mathrm{~mm}$ - and $10 \mathrm{~mm}-\mathrm{MgCl}_{2}$ were $4 \%$ and $40 \%$ greater, 
Table 2. Effect of phosphate on the overall reaction

The reaction from $5 \mathrm{~mm}-\mathrm{UDPG}$ and $4.25 \mathrm{~mm}-\left[{ }^{14} \mathrm{C}\right] \mathrm{G} 6 \mathrm{P}$ to trehalose was followed at $\mathrm{pH} 6.8$ in the presence and absence of $6 \mathrm{~mm}$-potassium phosphate as described in Methods. The data are from a single experiment.

\begin{tabular}{|c|c|c|c|c|c|c|c|}
\hline \multirow{2}{*}{$\begin{array}{l}\text { Time } \\
(\min )\end{array}$} & \multirow{2}{*}{$\begin{array}{c}\text { Phosphate } \\
(\mathrm{mM}) \ldots\end{array}$} & \multicolumn{2}{|c|}{ UDP $(\mu \mathrm{M})$} & \multicolumn{2}{|c|}{ T6P $(\mu \mathrm{M})$} & \multicolumn{2}{|c|}{ Trehalose $(\mu \mathrm{M})$} \\
\hline & & 0 & 6 & 0 & 6 & 0 & 6 \\
\hline 5 & & 315 & 162 & 299 & 132 & 16 & 30 \\
\hline 10 & & 661 & 402 & 582 & 293 & 79 & 109 \\
\hline 20 & & 1280 & 810 & 971 & 437 & 309 & 373 \\
\hline
\end{tabular}

respectively, than that with $5 \mathrm{mM}-\mathrm{EDTA} / 75 \mu \mathrm{M}-\mathrm{MgCl}_{2}$. In contrast, no TPP activity was observed at $4 \mathrm{mM}$ EDTA, and between $16 \mu \mathrm{M}$ - and $1 \mathrm{mM}-$ free $\mathrm{Mg}^{2+}$ a linear double-reciprocal plot was obtained with $K_{1 / 2}$ of $80 \mu \mathrm{M}$ $\mathrm{Mg}^{2+}$ (not shown). The optimal concentration of $\mathrm{MgCl}_{2}$ was between 1 and $2 \mathrm{mM}$.

With pure TPS/P, no UDP or ADP were formed when UDPG in the standard TPS reaction mixture was replaced by UDP-glucuronate or by ADP-glucose, respectively. Although they were not substrates, both these compounds caused $20 \%$ inhibition when added at $5 \mathrm{~mm}$ to standard reaction mixtures.

Potassium phosphate (pH 6.8) inhibited TPS activity, as has been reported previously (Cabib \& Leloir, 1958; Elander, 1968; Vandercammen et al., 1989), with a $K_{\mathrm{i}}$ of $5 \mathrm{~mm}$ (not shown). This is somewhat higher than that ( $2 \mathrm{mM}$ ) reported by Vandercammen et al. (1989), but lower than that reported by the earlier workers. In contrast, phosphate strongly activated TPP activity (Fig. 6). From the double-reciprocal plot in the inset of Fig. 6 a maximum activation of $5 \cdot 7$-fold and a $K_{\mathrm{a}}$ of $3 \mathrm{~mm}$ phosphate were calculated. Table 2 shows that the overall reaction from UDPG and G6P to trehalose was slightly stimulated by $6 \mathrm{~mm}$-potassium phosphate. Furthermore, the higher rate of trehalose production occurred with markedly less accumulation of T6P. Native TPS/P, like the highly purified TPS/P, was similarly stimulated by phosphate: when the phosphate in the standard TPP assay was replaced by $50 \mathrm{mM}-$ HEPES/KOH (pH 6.8), the activity of crude homogenate fell by $85 \%$.

\section{Discussion}

By purifying the TPS activity we obtained a high molecular mass protein preparation that also had high TPP activity and contained three major polypeptides, with molecular masses of 57 , about 86 and $93 \mathrm{kDa}$. The methods we have investigated so far (including gel- filtration in the presence of various concentrations of urea or in phosphate buffers) do not separate these polypeptides without destroying both activities. The ratio of the standard activities of TPP and TPS was $36 \pm 5 \%$ through the Heparin-Sepharose step and then decreased to $17 \pm 3 \%$ after the spontaneous proteolytic activation of TPS (Table 1). The almost identical peptide maps of the two larger polypeptides suggest that the $86 \mathrm{kDa}$ polypeptide is derived from the $93 \mathrm{kDa}$ polypeptide. This is supported by preliminary data showing that corresponding pairs of peptides from the two polypeptides have identical amino acid sequences $(\mathrm{N}$. Kalkkinen, R. Fagerström, J. Londesborough \& O. Vuorio, unpublished work). The staining intensities of the bands indicated a molar ratio of the $57 \mathrm{kDa}$ polypeptide to the sum of the 86 and $93 \mathrm{kDa}$ polypeptides of 1.4 . We conclude we have purified a complex that exhibits both TPS and TPP activities and contains roughly equal molar amounts of a short $(57 \mathrm{kDa})$ polypeptide and a long $(93 / 86 \mathrm{kDa})$ polypeptide that has been partially degraded. The Western blot (Fig. 5) suggests that the 'native' molecular mass of the long polypeptide is at least $115 \mathrm{kDa}$.

We do not yet know which polypeptide contains which active site. Possibly one of the polypeptides has a purely regulatory role. Changes in the molecular mass of the long polypeptide lead to increases in TPS activity with no change in TPP (Figs 4 and 5). This suggests that one end of the long polypeptide interacts with the TPS active site, but does not define the location of this active site.

TPS-activator was a relatively heat-stable protein $\left(50 \%\right.$ of its activity survived $10 \mathrm{~min}$ at $\left.55^{\circ} \mathrm{C}\right)$ and surprisingly large (a dimer of $58 \mathrm{kDa}$ subunits; Fig. 1). It had no effect on TPP activity, in either the usual assay system (Fig. 2) or when HEPES buffer was used instead of phosphate (not shown). The TPS activity of 'native' TPS/P did not absolutely require TPS-activator. Instead, the Michaelis constants for UDPG and G6P were decreased by TPS-activator towards the values exhibited by the pure (proteolysed) TPS/P complex in the absence of TPS-activator (Fig. 3). In the absence of TPSactivator, the apparent maximum velocities of 'native' TPS/P at infinite G6P and 5 mM-UDPG and at infinite UDPG and $25 \mathrm{~mm}-\mathrm{G} 6 \mathrm{P}$ were, respectively, $80 \%$ and $67 \%$ of the corresponding values at a saturating level of TPS-activator (Fig. 3). Thus, at saturating levels of both substrates, TPS-activator would have a negligible effect. These results suggested, as a working hypothesis, that the TPS active site is partially occluded by a flap of protein formed from one end of the long polypeptide of TPS/P. Access to the active site would be facilitated either by interaction with TPS-activator or by limited proteolysis of the long polypeptide, forming the 93 and $86 \mathrm{kDa}$ polypeptides observed in purified TPS/P. Panek \& Panek 
(1990) in a recent review state they have isolated a protein activator of TPS, but give no information about it.

Variation in the level of TPS-activator and limited proteolysis in vivo provide two new mechanisms by which trehalose synthesis might be regulated. The cytosolic concentration of phosphate may be another important factor, because as well as the previously reported (Cabib \& Leloir, 1958; Elander, 1968; Vandercammen et al., 1989) inhibition of TPS by phosphate, we found a strong activation of TPP at similar phosphate concentrations (Fig. 6). Lagunas \& Gancedo (1983) consider that free phosphate in yeast cytosol probably varies by a factor of 2 within the range 1 to $5 \mathrm{~mm}$. Table 2 shows that $6 \mathrm{~mm}$ phosphate modestly accelerated the overall reaction and markedly decreased accumulation of the intermediate, T6P. Even if variations in phosphate do not have a regulatory role, it seems likely that about $5 \mathrm{mM}^{-}$ phosphate is required for the proper functioning of TPS/P, to produce trehalose at a moderate steady-state concentration of T6P. In this connection, it is interesting that Piper \& Lockheart (1988) have isolated a temperature-sensitive mutant of $S$. cerevisiae that accumulates T6P above the restriction temperature.

We have not attempted to characterize the catalytic properties of the purified TPS/P in further detail, because it is not yet clear whether this form occurs in vivo. Further work is needed to investigate this possibility and to purify the native form of TPS/P.

We thank Richard Fagerström for advice and assistance with the peptide mapping. We are much indebted to Sirkka Kanervo for excellent technical assistance.

\section{References}

Aebersold, R. H., Leavitt, J., SaAvedra, R. A., Hood, L. E. \& Kent, S. B. H. (1987). Internal amino acid sequence analysis of proteins separated by one- or two-dimensional electrophoresis after in situ protease digestion on nitrocellulose. Proceedings of the National Academy of Sciences of the United States of America 84, 6970-6974.

AtTField, P. V. (1987). Trehalose accumulates in Saccharomyces cerevisiae during exposure to agents that induce heat shock response. FEBS Letters 225, 259-263

CABIB, E. \& Leloir, L. F. (1958). The biosynthesis of trehalose phosphate. Journal of Biological Chemistry 231, 259-275.

Crowe, J. H., Crowe, L. M., Carpenter, J. F. \& Aurell Wistrom, C. (1987). Stabilization of dry phospholipid bilayers and proteins by sugars. Biochemical Journal 242, 1-10.
ELANDER, M. (1968). Trehalose-6-phosphatsynthetase aus Bäckerhefe Arkiv för Kemi 31, 17-30.

Gadd, G. M., Chalmers, K. \& Reed, R. H. (1987). The role of trehalose in dehydration resistance in Saccharomyces cerevisiae. FEMS Microbiology Letters 48, 249-254.

Glick, N., Landman, A. D. \& Roufogalis, B. D. (1979). Correcting Lineweaver-Burk calculations of $V$ and $K_{\mathrm{m}}$. Trends in Biochemical Sciences 4, 82-83.

HAGER, D. A. \& BURGess, R. R. (1980). Elution of proteins from sodium dodecyl sulfate-polyacrylamide gels. Analytical Biochemistry 109, 76-86.

Hottiger, T., Schmutz, P. \& Wiemken, A. (1987a). Heat-induced accumulation and futile cycling of trehalose in Saccharomyces cerevisiae. Journal of Bacteriology 169, 5518-5522.

Hottiger, T., Boller, T. \& Wiemken, A. $(1987 \mathrm{~b})$. Rapid changes of heat and desiccation tolerance correlated with changes of trehalose content in Saccharomyces cerevisiae cells subjected to temperature shifts. FEBS Letters 220, 113-115.

Hottiger, T., Boller, T. \& Wiemken, A. (1989). Correlation of trehalose content and heat resistance in yeast mutants altered in the RAS/adenylate cyclase pathway: is trehalose a thermoprotectant? FEBS Letters 225, 431-434.

LAEMMLI, U. K. (1970). Cleavage of structural proteins during the assembly of the head of bacteriophage T4. Nature, London 227, 680 685.

Lagunas, R. \& Gancedo, C. (1983). Role of phosphate in the regulation of the Pasteur effect in Saccharomyces cerevisiae. European Journal of Biochemistry 137, 479-483.

Lillie, S. H. \& Pringle, J. R. (1980). Reserve carbohydrate metabolism in Saccharomyces cerevisiae: responses to nutrient limitation. Journal of Bacteriology 143, 1384-1394.

OdA, Y., Uno, K. \& OHTA, S. (1986). Selection of yeasts for breadmaking by the frozen-dough method. Applied and Environmental Microbiology 52, 941-943.

Panek, A. C., de Araujo, P. S., Moura Neto, V. \& Panek, A. D. (1987). Regulation of the trehalose-6-phosphate synthase complex in Saccharomyces. Current Genetics 11, 459-465.

PANeK, A. D. \& PANeK, A. C. (1990). Metabolism and thermotolerance function of trehalose in Saccharomyces; a current perspective. Journal of Biotechnology 14, 229-238.

Paschoalin, V. M. F., Silva, J. T. \& Panek, A. D. (1989). Identification of an ADPG-dependent trehalose synthase in Saccharomyces. Current Genetics 16, 81-87.

PIPER, P. W. \& LOCKHEART, A. (1988). A temperature-sensitive mutant of Saccharomyces cerevisiae defective in the specific phosphatase of trehalose biosynthesis. FEMS Microbiology Letters 49, 245-250.

Tenan, M. N., Ortiz, C. H., Dellamora-Ortiz, G. M., Mattoon, J. R. \& PANeK, A. D. (1985). Relationships between mutations affecting protein kinase and accumulation of energy reserves in Saccharomyces cerevisiae. FEMS Microbiology Letters 26, 217-220.

Thevelein, J. M. (1988). Regulation of trehalase activity by phosphorylation-dephosphorylation during developmental transitions in fungi. Experimental Mycology 12, 1-12.

VANDERCAmmen, A., François, J. \& Hers, H.-G. (1989). Characterization of trehalose-6-phosphate synthase and trehalose-6-phosphate phosphatase of Saccharomyces cerevisiae. European Journal of Biochemistry 182, 613-620.

WARBURG, O. \& ChRISTIAN, W. (1941). Isolierung und Kristallisation des Gärungsferments Enolase. Biochemische Zeitschrift 310, 384-421. 